\title{
Electrochemical Degradation of PAHs in Produced Water Using $\mathrm{Ti} / \mathrm{Sb}_{2} \mathrm{O}_{5}-\mathrm{SnO}_{2}-\mathrm{IrO}_{2}$ Anode \\ Asim YAQUB, ${ }^{a}, *$ Mohamed Hasnain ISA, ${ }^{a}$ Shamsul Rahman Mohamed KUTTY, ${ }^{a}$ and Huma AJAB
}

\author{
a Civil Engineering Department, Universiti Teknologi PETRONAS, \\ Bandar Seri Iskandar 31750 Tronoh, Perak, Malaysia \\ b Chemical Engineering Department, Universiti Teknologi PETRONAS, \\ Bandar Seri Iskandar 31750 Tronoh, Perak, Malaysia
}

\section{*Corresponding author: environment_green@yahoo.com}

\begin{abstract}
In the study, ternary oxides coated $\mathrm{Ti} / \mathrm{SnO}_{2}-\mathrm{Sb}_{2} \mathrm{O}_{5}-\mathrm{IrO}_{2}$ anode was used for degradation of 16 priority polycyclic aromatic hydrocarbons (PAHs) in a laboratory scale electrochemical batch reactor. To determine the optimum conditions for electrochemical degradation of PAHs from produced water, Box-Behnken design was used with three independent variables, viz., current density, $\mathrm{pH}$ and electrolysis time and response variable, viz., $\Sigma \mathrm{PAHs}$ removal \%. Quadratic regression model was recommended as the best fit model. The results of Analysis of Variances (ANOVA) exhibited that the regression model adequately described the functional relationship between the independent variables and the response. This study affirmed that electrochemical degradation of PAHs followed first-order kinetics.
\end{abstract}

(C) The Electrochemical Society of Japan, All rights reserved.

Keywords : Electrochemical Degradation, PAHs, Produced Water, Optimization

\section{Introduction}

Produced water $(\mathrm{PW})$ is the largest wastewater stream from oil and gas exploration. The oil and gas industry produces approximately 14 billion barrels of water annually. ${ }^{1,2}$ Volumes vary considerably throughout the lifetime of a field. Produce water is primarily relatively warm water from the oil reservoir. It contains dissolved and dispersed oils, high salt concentrations, heavy metals, high petroleum hydrocarbons and on occasions naturally occurring radioactive materials. ${ }^{3}$ Owing to its long contact with hydrocarbonbearing formations, numerous aliphatic and aromatic hydrocarbons, polycyclic aromatic hydrocarbons (PAHs) and phenols are also found in produced water.

More than 160 PAHs have been characterized in nature, however only sixteen have been classified as priority pollutants by the USEPA due to their toxic properties. ${ }^{4}$ Feminization in male fish found on exposing them to very low levels of PAHs in produced water, which considerably diminishes fertility and delays the spawning period by quite a lot of weeks. ${ }^{5}$ Also cancer in fish and especially in benthic organisms has been related to pollution arising from offshore production installations. ${ }^{6}$

Electrochemical treatment effectively oxidized toxic organics in various types of wastewater. ${ }^{7-10}$ It is well known that the electrode material is the key factor in the development of electrochemical oxidation techniques and the effectiveness of electrochemical oxidation depends on the nature of the anodes. ${ }^{11-14}$ During oxidation of organic pollutants, electrodes require high oxygen evolution reaction to produce high concentration of $\mathrm{OH}^{*}$ radicals. ${ }^{12}$ Since their development in the 1960 s by Beer for the chlorine production industry, dimensionally stable anodes (DSAs) have become the most important electrodes in electrochemical engineering. ${ }^{15}$ DSAs consist of a titanium substrate covered with conductive metallic oxides coating e.g. $\mathrm{IrO}_{2}, \mathrm{RuO}_{2}, \mathrm{SnO}_{2}, \mathrm{TiO}_{2}$ etc. used as electro-catalyst. The advantages of these metal oxide anodes include their high durability, good electro-catalytic activity against organic pollutants, and low production cost. DSAs have been successfully applied as anode in a number of important electrolytic processes, such as oxygen and chlorine evolution or the electrochemical oxidation of bio-refractory organic pollutants in wastewaters. ${ }^{13,14}$

Antimony doped $\mathrm{SnO}_{2}$ oxide anodes are promising candidates for the electrochemical degradation of organic pollutants in wastewater because of their high over-potential for oxygen evolution, their ability to generate hydroxyl radicals and their lower cost compared to precious metal oxides; however, the commercial application of $\mathrm{Ti} / \mathrm{SnO}_{2}-\mathrm{Sb}_{2} \mathrm{O}_{5}$ is hampered by its short lifetime. $\mathrm{IrO}_{2}$ is the most widely investigated electro-catalyst for $\mathrm{O}_{2}$ evolution. ${ }^{15}$ In recent studies it was reported that the addition of iridium oxide $\left(\mathrm{IrO}_{2}\right)$ to the $\mathrm{SnO}_{2}-\mathrm{Sb}_{2} \mathrm{O}_{5}$ coating greatly increases service life. ${ }^{16,17}$ This has been attributed to the incorporation of $\mathrm{IrO}_{2}$ in the $\mathrm{SnO}_{2}-\mathrm{Sb}_{2} \mathrm{O}_{5}$ coating by diffusion during electrode preparation. In $\mathrm{Ti} / \mathrm{SnO}_{2}$ $\mathrm{Sb}_{2} \mathrm{O}_{5}-\mathrm{IrO}_{2}$ anode, $\mathrm{SnO}_{2}$ acts as a dispersing agent, $\mathrm{Sb}_{2} \mathrm{O}_{5}$ as a doping agent and $\mathrm{IrO}_{2}$ acts as a catalyst. ${ }^{18}$ Such ternary oxides anodes are among the best electrocatalysts being able to produce physiosorbed hydroxyl radicals on their surface from water discharge. For example, Tian et al. found that DSA $\left(\mathrm{OH}^{*}\right)$ reacted with nitrophenolic compounds leading to $85-90 \%$ removal over $3 \mathrm{~h}$ of electrolysis. ${ }^{19}$

Optimization plays a key role in environmental engineering applications since the best system performance mainly corresponds to an optimum point or optimum range of operating parameter values. Majority of wastewater treatment processes are multivariable and optimization through the classical method of one variable at a time is inflexible, unreliable and time-consuming. Thus, response surface methodology (RSM), as an efficient design and widely used technique, can be adapted for parameters optimization of various wastewater treatment processes. ${ }^{20-25}$

The main objectives of this research were to study the degradation kinetics and optimization of operational parameters for electrochemical degradation of PAHs on $\mathrm{Ti} / \mathrm{Sb}_{2} \mathrm{O}_{5}-\mathrm{SnO}_{2}-\mathrm{IrO}_{2}$ anode using Box-Behnken design. 
Electrochemistry, 82(11), 979-984 (2014)

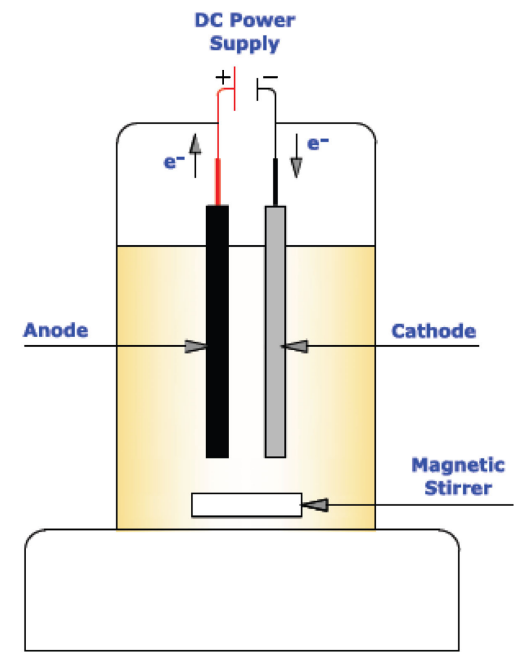

Figure 1. (Color online) Schematic set-up of the electrochemical reactor.

\section{Materials and Methods}

\subsection{Chemicals and apparatus}

Tin (IV) chloride $\left(\mathrm{SnCl}_{4}\right)$ extra pure, antimony (III) chloride $\mathrm{SbCl}_{3}(99.0 \%)$, iridium (III) chloride hydrate $\left(\mathrm{IrCl}_{3} \cdot \mathrm{XH}_{2} \mathrm{O}\right)$, ethylene glycol and acetic acid (glacial) anhydrous were purchase from Merck Chemicals. Dichloromethane DCM (HPLC grade) was used as solvent for the extraction of PAHs from water samples. The DCM was concentrated under vacuum using rotary evaporator (Rotavapor ${ }^{\circledR}$ R-205/Vacuum Controller V-800/Heating Bath B-490 manufacture by BÜCHI Switzerland).

\subsection{Electrochemical cell}

Real PW samples locally collected from an offshore oil exploration site were used for all electrochemical experiments. A laboratory scale electrochemical batch reactor was used for electrochemical oxidation experiments for degradation of PAHs in PW. All experiments were performed under galvanostatic conditions (under controlled current). Dimensions of electrodes used in this study were $8 \mathrm{~cm} \times 10 \mathrm{~cm} \times 0.2 \mathrm{~cm}$. Volume of $\mathrm{PW}$ used in electrochemical cell was $100 \mathrm{ml}$. The electrochemical cell consisted of an anode ( $\left.\mathrm{Ti} / \mathrm{SnO}_{2}-\mathrm{Sb}_{2} \mathrm{O}_{5}-\mathrm{IrO}_{2}\right)$ and a cathode ( $\mathrm{Ti}$ plate) connected to DC power supply. The electrode inter-distance was $2 \mathrm{~cm}$ in all experiments. Schematic set-up of the electrochemical cell is shown in Fig. 1.

\subsection{Anode coating}

Titanium plates for anodes were coated by thermal decomposition method. ${ }^{16-18}$ Firstly the titanium plate was pre-treated before coating. Three coating materials $(\mathrm{CM}) \mathrm{SnCl}_{4}, \mathrm{SbCl}_{3}$ and $\mathrm{IrCl}_{3} \cdot \mathrm{xH}_{2} \mathrm{O}$ were dissolved in acetic acid (AA) and ethylene-glycol (EG) in ratios of (CM:AA:EG) $(2 \mathrm{ml}: 2 \mathrm{ml}: 10 \mathrm{ml}),(2 \mathrm{~g}: 2 \mathrm{ml}: 10 \mathrm{ml})$ and $(0.1 \mathrm{~g}: 2 \mathrm{ml}: 10 \mathrm{ml})$ respectively at $60^{\circ} \mathrm{C}$ for $1 \mathrm{hr}$. Proportion of 80:10:10 was taken from $\mathrm{SnCl}_{4}, \mathrm{SbCl}_{3}$ and $\mathrm{IrCl}_{3} \cdot \mathrm{xH}_{2} \mathrm{O}$ solutions repectively to make final precursor solution. It was applied (about 20 times) on a degreased and etched Ti plate. After each application the solvent was removed by drying at $200^{\circ} \mathrm{C}$ for $10 \mathrm{~min}$ to evaporate the solvent and after 10 applications the plate was dried at $500^{\circ} \mathrm{C}$ for $10 \mathrm{~min}$ and finally heated at $600^{\circ} \mathrm{C}$ for $1 \mathrm{~h}$ to remove all the organic contents.

\subsection{Analytical techniques}

Priority PAHs were extracted by Liquid-Liquid Extraction GC-MS Method. ${ }^{26}$ For $100 \mathrm{ml}$ sample of PW, $12.5 \mathrm{ml}, 5 \mathrm{ml}, 5 \mathrm{ml}$
Table 1. GC-MS set up and quantification of PAH in PW.

\begin{tabular}{|c|c|c|c|c|}
\hline Component & \multicolumn{4}{|c|}{ Conditions } \\
\hline GC-MS & \multicolumn{4}{|c|}{ Agilent Model GC-MS 5975C } \\
\hline Column & \multicolumn{4}{|c|}{$\begin{array}{l}\text { DB 5MS column ( } 30 \mathrm{~m} \text { length, } 0.25 \mathrm{~mm} \\
\text { diameter, } 0.25 \mu \mathrm{m} \text { thickness })\end{array}$} \\
\hline Column temperature & \multicolumn{4}{|c|}{$\begin{array}{l}60 \text { to } 175^{\circ} \mathrm{C} \text { at } 6^{\circ} \mathrm{C} / \mathrm{min} \text {, then increased } \\
\text { at } 3^{\circ} \mathrm{C} / \mathrm{min} \text { until } 240^{\circ} \mathrm{C} \text { and finally held } \\
\text { at } 300^{\circ} \mathrm{C} \text { for } 7 \mathrm{~min}\end{array}$} \\
\hline $\begin{array}{l}\text { Injector and transfer line } \\
\text { temperatures }\end{array}$ & \multicolumn{4}{|c|}{ e 280 and $300^{\circ} \mathrm{C}$} \\
\hline Data acquisition mode & \multirow{2}{*}{\multicolumn{4}{|c|}{$\begin{array}{l}\text { Selected ion monitoring (SIM) mode } \\
\text { Helium }\end{array}$}} \\
\hline Carrier gas & & & & \\
\hline PAHs & $\begin{array}{l}\text { No. of } \\
\text { benzene } \\
\text { rings }\end{array}$ & $\begin{array}{l}\text { Molecular } \\
\text { weight }\end{array}$ & $\begin{array}{l}\text { Retention } \\
\text { time (min) }\end{array}$ & $\begin{array}{l}\text { Concen. } \\
\text { of PAHs } \\
(\mu \mathrm{g} / 1)\end{array}$ \\
\hline Naphthalene & 2 & 128.17 & 7.57 & 58.06 \\
\hline Acenaphthylene & 3 & 152.20 & 11.19 & 13.66 \\
\hline Acenaphthene & 3 & 154.20 & 11.61 & 6.42 \\
\hline Fluorene & 3 & 166.22 & 12.84 & 14.43 \\
\hline Phenanthrene & 3 & 178.23 & 15.12 & 2.29 \\
\hline Anthracene & 3 & 178.23 & 15.13 & 15.44 \\
\hline Fluoranthene & 4 & 202.26 & 17.96 & 12.77 \\
\hline Pyrene & 4 & 202.26 & 18.48 & 12.44 \\
\hline Benz(a)anthracene & 4 & 228.28 & 21.38 & 6.87 \\
\hline Chrysene & 4 & 228.28 & 21.46 & 2.82 \\
\hline Benzo(b)fluoranthene & 5 & 252.31 & 23.77 & 4.59 \\
\hline Benzo(k)fluoranthene & 5 & 252.31 & 23.83 & 2.24 \\
\hline Benzo(a)pyrene & 5 & 252.31 & 24.45 & 3.61 \\
\hline Indeno(1,2,3-cd)pyrene & 6 & 276.33 & 27.28 & 2.28 \\
\hline Dibenz $(\mathrm{a}, \mathrm{h})$ anthracene & 6 & 278.34 & 27.40 & 1.75 \\
\hline Benzo $(\mathrm{g}, \mathrm{h}, \mathrm{i})$ perylene & 6 & 276.33 & 28.05 & 1.19 \\
\hline
\end{tabular}

volumes of Dichloromethane (DCM) was used as solvent for serial extraction of PAHs. For GC-MS analysis, the final volume of PAHs extracted sample through rotary evaporator was $1 \mathrm{ml}$. GC-MS was used for the detection of each PAH (conditions for GC-MS SIM mode and PAHs characteristics are shown in Table 1). Each PAH was separately quantified using a five-point calibration of mixed standard solutions. Intermediates were determined by GS-MS scan mode. Characteristics of PW (Table 2) were determined by standard methods for the examination of water and wastewater. ${ }^{27}$

\subsection{Experimental design}

A three-level factorial design was established with the help of the Design Expert 6.0.7 software. Box-Behnken design (BBD) was selected to determine the suitable combination of three independent variables $\mathrm{X}_{1}$ : current density $\left(\mathrm{mA} / \mathrm{cm}^{2}\right), \mathrm{X}_{2}$ : initial $\mathrm{pH}$, and $\mathrm{X}_{3}$ : electrolysis time $(\mathrm{h})$ for optimization of PAHs degradation. BBD yielded an experimental plan that consisted of 17 experiments as shown in Table 3.

Mathematical relationship of response (Y: PAHs removal \%) and independent variables $\left(\mathrm{X}_{1}\right.$ : current density, $\mathrm{X}_{2}$ : $\mathrm{pH}$, and $\mathrm{X}_{3}$ : electrolysis time) was represented by the second order polynomial regression model shown below (Eq. 1).

$$
\begin{aligned}
\mathrm{Y}= & \beta_{0}+\beta_{1} \mathrm{X}_{1}+\beta_{2} \mathrm{X}_{2}+\beta_{3} \mathrm{X}_{3}+\beta_{11} \mathrm{X}_{1}{ }^{2}+\beta_{22} \mathrm{X}_{2}{ }^{2} \\
& +\beta_{33} \mathrm{X}_{3}^{2}+\beta_{12} \mathrm{X}_{1} \mathrm{X}_{2}+\beta_{13} \mathrm{X}_{1} \mathrm{X}_{3}+\beta_{23} \mathrm{X}_{2} \mathrm{X}_{3}
\end{aligned}
$$


Table 2. Characteristics of produced water [27].

\begin{tabular}{lc}
\hline Chemical parameters of produced water $(\mathrm{mg} / \mathrm{l})$ \\
\hline BOD & 590 \\
COD & 1347 \\
TOC & 1022 \\
Phenol & 13.8 \\
NH3-N & 8.5 \\
Chlorides & $>10,000$ \\
Sulfates & 156 \\
\hline Physical parameters of produced water \\
\hline pH & 7.8 \\
Conductivity & $30,000 \mathrm{mS} / \mathrm{cm}$ \\
Turbidity & $72 \mathrm{NTU}$ \\
TDS & $16105(\mathrm{mg} / \mathrm{l})$ \\
TSS & $250(\mathrm{mg} / \mathrm{l})$ \\
\hline
\end{tabular}

where $\mathrm{Y}$ is the predicted response; $\beta_{0}$ is constant; $\beta_{1}, \beta_{2}, \beta_{3}$ are linear coefficients; $\beta_{11}, \beta_{22}, \beta_{33}$ are quadratic coefficients; $\beta_{12}, \beta_{13}, \beta_{23}$ are cross product coefficients; $\mathrm{X}_{1}, \mathrm{X}_{2}$, and $\mathrm{X}_{3}$ are the levels of independent variables. ${ }^{28}$ The significance of each coefficient in the equation was determined by F-test and P-values.

\section{Results and Discussion}

\subsection{Modeling and optimization of PAHs degradation}

The effects of three independent variables: current density $\left(\mathrm{X}_{1}\right)$, $\mathrm{pH}\left(\mathrm{X}_{2}\right)$ and electrolysis time $\left(\mathrm{X}_{3}\right)$ on electrochemical PAHs degradation were determine according to the completely randomized experimental design shown in Table 3. Experimental data were fitted into a second order regression model. Relationship between PAHs removal efficiency and the variables is expressed by the following second-order polynomial equation.

$$
\begin{aligned}
\mathrm{Y}_{(\Sigma \text { PAHs Removal \% })=} & +87.56+9.27 \mathrm{X}_{1}+1.77 \mathrm{X}_{2}+5.69 \mathrm{X}_{3} \\
& -5.23 \mathrm{X}_{1}^{2}+2.27 \mathrm{X}_{3}^{2}+2.77 \mathrm{X}_{1} \mathrm{X}_{3}
\end{aligned}
$$

The model terms in Eq. (2) are after the elimination of insignificant variables. In this case significant model terms are $\mathrm{X}_{1}, \mathrm{X}_{2}, \mathrm{X}_{3}, \mathrm{X}_{1}^{2}$, $\mathrm{X}_{3}^{2}, \mathrm{X}_{1} \mathrm{X}_{2}$ and $\mathrm{X}_{1} \mathrm{X}_{3}$. It shows that efficiency of $\mathrm{Ti} / \mathrm{SnO}_{2}-\mathrm{Sb}_{2} \mathrm{O}_{5^{-}}$ $\mathrm{IrO}_{2}$ significantly depends on current density, $\mathrm{pH}$, time and combination of current density with electrolysis time. Based on statistical analysis the model terms were highly significant with very low probability value $(0.034$ to $<0.0001)$.

ANOVA results for the study are presented in Table 4. Values of "Prob > F" less than 0.05 indicate model terms are significant. It was noted that the model terms of independent variables were significant at $99 \%$ confidence level. The Model F-value of 151.31 implies the model is significant. There is only a $0.01 \%$ chance that a "Model F-Value" this large could occur due to noise. F-value 1.17 implies the Lack of Fit is not significant as $\mathrm{P}$ value was greater than 0.05 . There is a $42.66 \%$ chance that a "Lack of Fit F-value" this large could occur due to noise. In this case Lack of Fit is good "Prob $>$ F" for Lack of Fit should be greater than 0.10. For response, coefficient of determination $\mathrm{R}^{2}$ value was 0.995 which was in reasonable agreement with the adjusted $R^{2}$ of 0.988 . It showed high significant regression at $95 \%$ confidence level.

Figure 2 shows the 3D surface plots to facilitate the interpretation of effects $\mathrm{X}_{1}, \mathrm{X}_{2}$ and $\mathrm{X}_{3}$ on response $\mathrm{Y}$ ( $\Sigma$ PAHs removal \%). Figure $2 \mathrm{a}$ shows the surface plot drawn at actual factor $X_{3}=2.5 \mathrm{~h}$. Surface plot was found straight and smooth with response of $80.5 \%$ at $X_{1}$ values of 4.46 and $4.47 \mathrm{~mA} / \mathrm{cm}^{2}$ and $X_{2}$ value of 3.1 and 8.98 respectively. Contour lines show non-linear trend at maximum
Table 3. Experimental design and response for electrochemical

\begin{tabular}{|c|c|c|c|c|c|}
\hline \multirow[b]{3}{*}{ Std. order } & \multicolumn{3}{|c|}{ Independent variable } & \multirow{2}{*}{\multicolumn{2}{|c|}{$\begin{array}{c}\text { Response } \\
(\Sigma \text { PAHs removal \%) }\end{array}$}} \\
\hline & $\mathrm{X}_{1}$ & $\mathrm{X}_{2}$ & $X_{3}$ & & \\
\hline & $\begin{array}{c}\text { Current } \\
\text { density } \\
\left(\mathrm{mA} / \mathrm{cm}^{2}\right)\end{array}$ & $\mathrm{pH}$ & $\begin{array}{c}\text { Time } \\
\text { (hour) }\end{array}$ & $\begin{array}{c}\text { Actual } \\
\text { value }\end{array}$ & $\begin{array}{l}\text { Predicted } \\
\text { value }\end{array}$ \\
\hline 1 & 3.33 & 3 & 2.5 & 74.80 & 74.52 \\
\hline 2 & 10.00 & 3 & 2.5 & 86.26 & 87.52 \\
\hline 3 & 3.33 & 9 & 2.5 & 73.77 & 72.51 \\
\hline 4 & 10.00 & 9 & 2.5 & 96.33 & 96.61 \\
\hline 5 & 3.33 & 6 & 1.0 & 67.11 & 68.58 \\
\hline 6 & 10.00 & 6 & 1.0 & 90.18 & 90.12 \\
\hline 7 & 3.33 & 6 & 4.0 & 82.90 & 82.96 \\
\hline 8 & 10.00 & 6 & 4.0 & 98.12 & 98.52 \\
\hline 9 & 6.67 & 3 & 1.0 & 84.40 & 83.19 \\
\hline 10 & 6.67 & 9 & 1.0 & 87.10 & 86.88 \\
\hline 11 & 6.67 & 3 & 4.0 & 94.52 & 94.74 \\
\hline 12 & 6.67 & 9 & 4.0 & 96.91 & 98.11 \\
\hline 13 & 6.67 & 6 & 2.5 & 87.54 & 87.55 \\
\hline 14 & 6.67 & 6 & 2.5 & 88.88 & 87.55 \\
\hline 15 & 6.67 & 6 & 2.5 & 87.54 & 87.55 \\
\hline 16 & 6.67 & 6 & 2.5 & 87.22 & 87.55 \\
\hline 17 & 6.67 & 6 & 2.5 & 86.60 & 87.55 \\
\hline
\end{tabular}
removal of PAHs.

Table 4. ANOVA for response surface quadratic model $\mathrm{Ti} / \mathrm{SnO}_{2}-$ $\mathrm{Sb}_{2} \mathrm{O}_{5}-\mathrm{IrO}_{2}$.

\begin{tabular}{lrcrrr}
\hline Source & $\begin{array}{r}\text { Sum of } \\
\text { squares }\end{array}$ & DF & $\begin{array}{r}\text { Mean } \\
\text { square }\end{array}$ & $\begin{array}{c}\mathrm{F} \\
\text { value }\end{array}$ & Prob $>$ F \\
\hline Model & 1013.62 & 9 & 112.62 & 151.31 & $<0.0001$ \\
$\mathrm{X}_{1}$ & 606.22 & 1 & 606.21 & 814.45 & $<0.0001$ \\
$\mathrm{X}_{2}$ & 24.96 & 1 & 24.95 & 33.53 & 0.0007 \\
$\mathrm{X}_{3}$ & 210.02 & 1 & 210.02 & 282.16 & $<0.0001$ \\
$\mathrm{X}_{1}{ }^{2}$ & 107.13 & 1 & 107.13 & 143.93 & $<0.0001$ \\
$\mathrm{X}_{2}{ }^{2}$ & 0.33 & 1 & 0.33 & 0.44 & 0.5293 \\
$\mathrm{X}_{3}{ }^{2}$ & 35.36 & 1 & 35.36 & 47.52 & 0.0002 \\
$\mathrm{X}_{1} \mathrm{X}_{2}$ & 30.80 & 1 & 30.80 & 41.38 & 0.0004 \\
$\mathrm{X}_{1} \mathrm{X}_{3}$ & 5.11 & 1 & 5.11 & 6.86 & 0.0344 \\
$\mathrm{X}_{2} \mathrm{X}_{3}$ & 0.024 & 1 & 0.02 & 0.032 & 0.8625 \\
Residual & 5.21 & 7 & 0.74 & & \\
Lack of fit & 2.43 & 3 & 0.81 & 1.17 & 0.4266 \\
Pure error & 2.78 & 4 & 0.69 & & \\
\hline
\end{tabular}

values of $X_{1}$ and all $X_{2}$ values. In Fig. $2 b X_{2}=6$ is actual factor between $X_{1}$ and $X_{3}$. Surface plot and contour lines show curved structure which indicated that higher response can be predicted if one of $\mathrm{X}_{1}$ or $\mathrm{X}_{3}$ has higher values. Similarly in the case of Fig. 2c $\mathrm{X}_{1}=0.67 \mathrm{~mA} / \mathrm{cm}^{2}$ taken as actual factor where surface plot was found to be linear between $X_{2}$ and $X_{3}$ values 3 to 9 and 1 to $2.5 \mathrm{hr}$ respectively. Inclination in surface plot was found for a combination of the 2 independent variables, at $X_{2}$ above 6 and the $X_{3}$ between the ranges of $3.25-4 \mathrm{hr}$ with prediction of high response $\%$.

To check that selected model provides adequate approximation of real system or not, Fig. 3a shows normal probability plot of the studentized residuals. It is the difference between actual and 


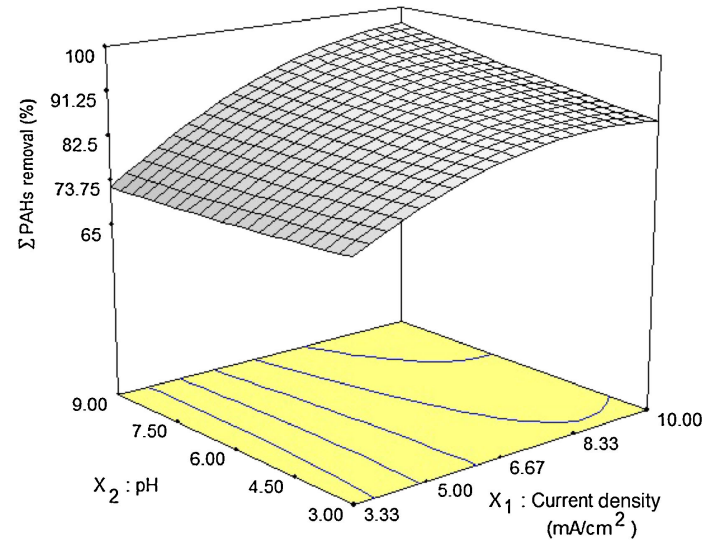

(a)

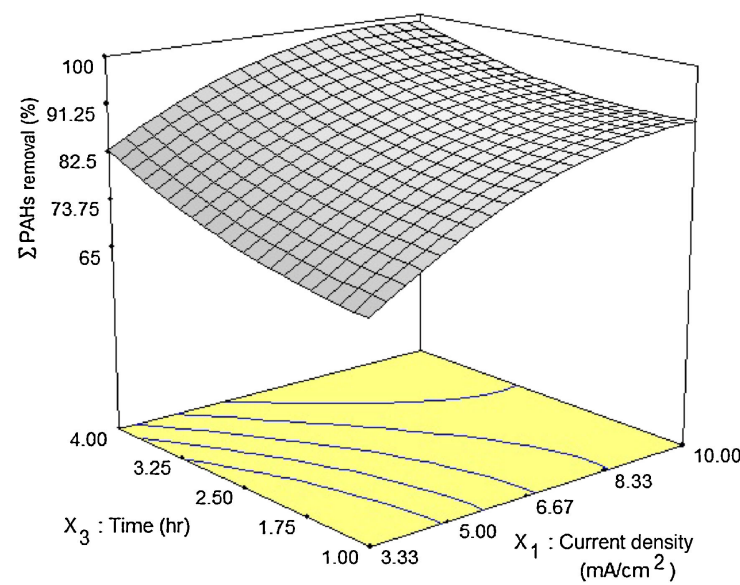

(b)

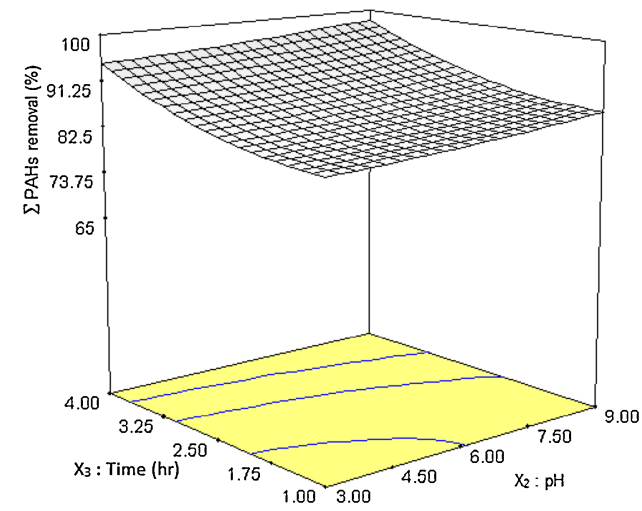

(c)

Figure 2. (Color online) Effect of electrolysis time (a) $\mathrm{pH}$ (b) and current density (c) on $\mathrm{Ti} / \mathrm{SnO}_{2}-\mathrm{Sb}_{2} \mathrm{O}_{5}-\mathrm{IrO}_{2}$ efficiency.

predicted response for PAH removal. It is clear from figure that residual follow a straight line and falls within \pm 2.13 . Figure $3 b$ shows normal distribution plot between actual and predicted response. All the data points in the plot lies close to straight line which indicates that data is fairly distributed.

Optimum condition was found by using numerical model considering all the parameters in range and for maximum PAH removal. The optimized condition obtained at current density of $8.77 \mathrm{~mA} / \mathrm{cm}^{2}, \mathrm{pH} 8.51$ and electrolysis time 2.5 hour shows maximum removal of $92.72 \%$. On same optimized conditions experimental value of PAHs removal was $90.56 \%$.

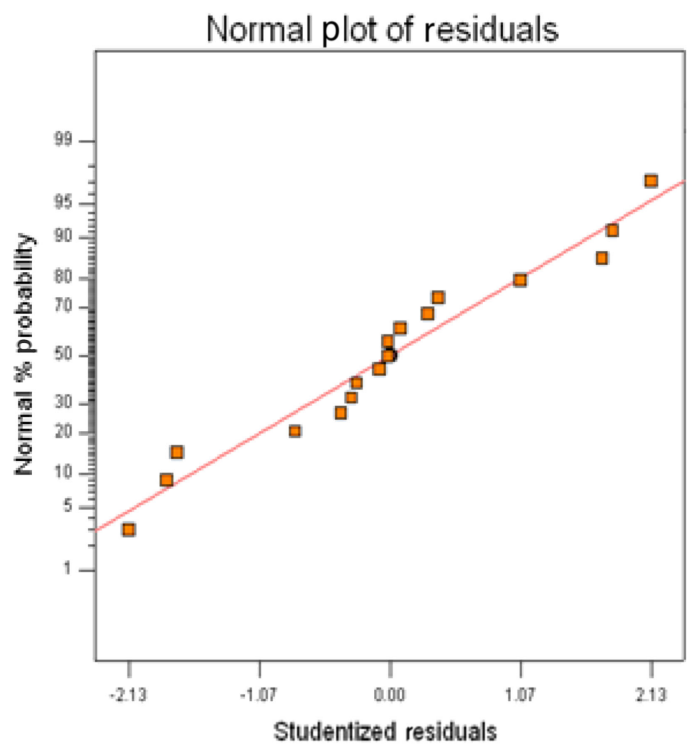

(a)

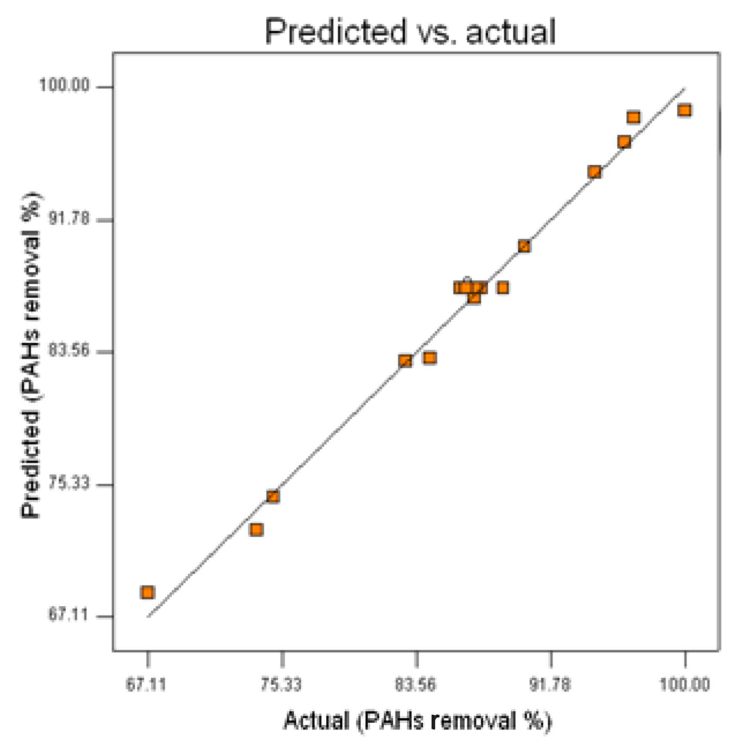

(b)

Figure 3. (Color online) Normal plot of residuals (a) scttered diagram of predicted response vs actual response (b) for PAHs at $\mathrm{Ti} / \mathrm{SnO}_{2}-\mathrm{Sb}_{2} \mathrm{O}_{5}-\mathrm{IrO}_{2}$.

\subsection{Degradation kinetics of PAHs in PW}

In electrochemical process individual contribution of each of direct/indirect oxidation is imperative for total removal of pollutants. Both the processes are considered for development of a kinetic model for the PAHs degradation in a batch electrochemical reactor by $\mathrm{Ti} / \mathrm{SnO}_{2}-\mathrm{Sb}_{2} \mathrm{O}_{5}-\mathrm{IrO}_{2}$. A first-order model (Eq. 3$)^{27}$ was attempted to determine the rate constant $k$ for the experimentalkinetic data of each PAHs degradation. Plots of $\ln (\mathrm{C} / \mathrm{Co})$ versus time (Fig. 4) shows linear relationship confirming that the degradation of all PAHs followed first-order kinetic behaviour.

$$
\ln \left(\frac{[\mathrm{PAH}]_{t}}{[\mathrm{PAH}]_{o}}\right)=-k t
$$

The kinetic rate constants $k$ for each PAHs were calculated from the magnitude of the slopes of the straight lines and are shown in Table 5 . Rate constant was positively affected by increase in current density in all experiments. The rate constant $k$ values increased with current density. Acenaphthylene and fluorene showed higher $k$ 


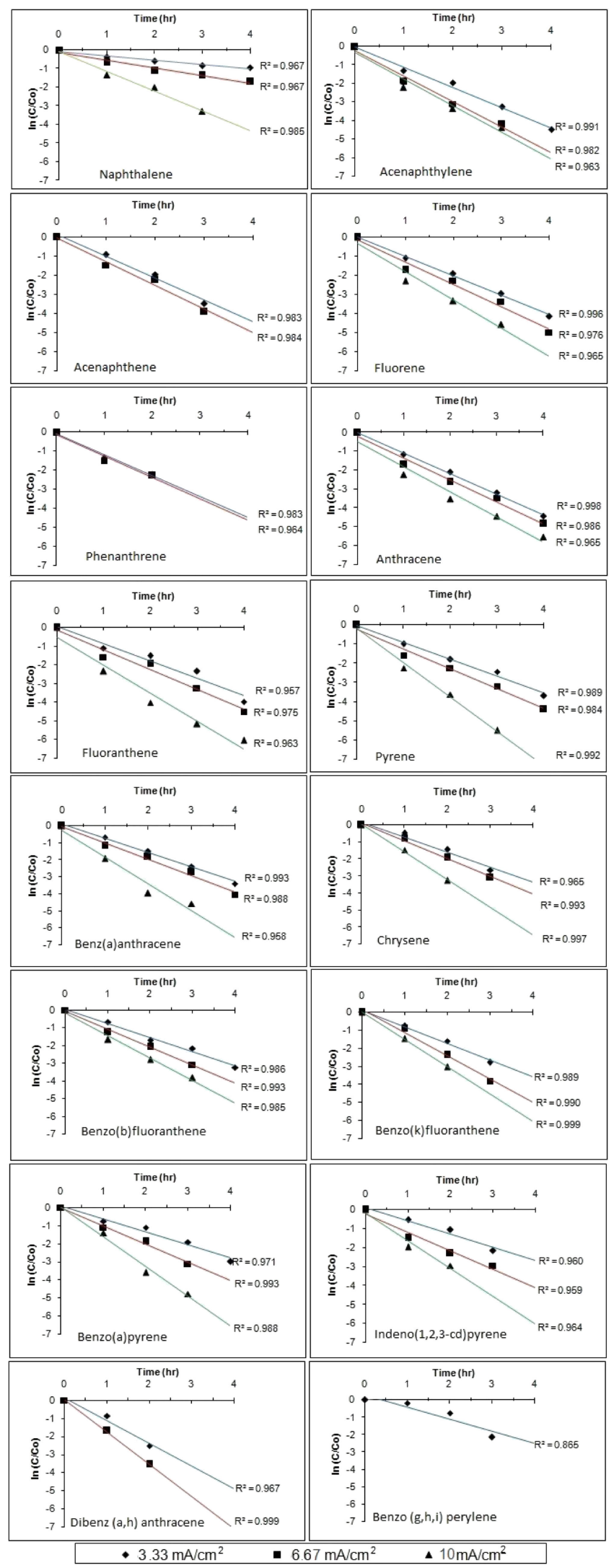

Figure 4. (Color online) Plots of $\ln \left(\mathrm{C} / \mathrm{C}_{\mathrm{o}}\right)$ vs. time for the degaradation of PAHs at $3.33,6.67$ and $10 \mathrm{~mA} / \mathrm{cm}^{2}$.

values at 3.33, 6.67 and $10 \mathrm{~mA} / \mathrm{cm}^{2}$ respectively among 3 benzene ring PAHs. Similarly in case of 4 benzene rings PAHs, fluoranthene had higher $k$ values at $10 \mathrm{~mA} / \mathrm{cm}^{2}$. In case of 5 and 6 benzene ring PAHs decrease in $k$ values was observed because of their low solubility and molecular structure.
Table 5. Valuse of rate constant $k$ at different current densities and electrolysis time.

\begin{tabular}{lllc}
\hline & \multicolumn{3}{c}{ Rate constant $k$} \\
\cline { 1 - 3 } Current density $\left(\mathrm{mA} / \mathrm{cm}^{2}\right)$ & 3.33 & 6.67 & 10 \\
\cline { 1 - 4 } PAHs & & & \\
\hline Naphthalene & 0.018 & 0.033 & 0.053 \\
Acenaphthylene & 0.070 & 0.074 & 0.085 \\
Acenaphthene & 0.045 & 0.058 & 0.046 \\
Fluorene & 0.063 & 0.08 & 0.084 \\
Phenanthrene & 0.040 & 0.044 & 0 \\
Anthracene & 0.067 & 0.085 & 0.107 \\
Fluoranthene & 0.057 & 0.073 & 0.118 \\
Pyrene & 0.056 & 0.075 & 0.090 \\
Benz(a)anthracene & 0.047 & 0.062 & 0.084 \\
Chrysene & 0.031 & 0.042 & 0.051 \\
Benzo(b)fluoranthene & 0.047 & 0.051 & 0.067 \\
Benzo(k)fluoranthene & 0.037 & 0.050 & 0.049 \\
Benzo(a)pyrene & 0.041 & 0.046 & 0.071 \\
Indeno(1,2,3-cd) pyrene & 0.034 & 0.068 & 0.056 \\
Dibenz (a,h) anthracene & 0.035 & 0.057 & 0.035 \\
Benzo (g,h,i) perylene & 0.020 & 0.012 & 0.029 \\
\hline
\end{tabular}

\subsection{Reactivity of $\mathrm{OH}^{\bullet}$ radicals and PAHs}

Organic compounds in aqueous solutions can be oxidized on an anode by direct electron transfer and indirect oxygen atom transfer. ${ }^{29}$ During electrolysis of aqueous solution oxidation of water molecules on the electrode surface gives rise to formation of hydroxyl radicals $\left(\mathrm{OH}^{*}\right)$ (Eq. 4). The $\mathrm{OH}^{*}$ radicals readily react with PAHs adsorbed on metallic oxides surface $\left(\mathrm{MO}_{\mathrm{x}}\right)$ of anode (Eq. 5) commencing the direct electron transfer from adsorbed PAH to the electrode. During the indirect oxygen atom transfer, oxygen radicals, especially $\mathrm{OH}^{*}$ radicals help in the oxidation of PAHs. Hydroxylation strips off outer hydrogen atom and replaces it with a hydroxyl group and converted to possible intermediate. GC-MS detected possible intermediates that contains hydroxyl group they are listed in Table 6 and their chromatogram is shown in Fig. 5. Further hydroxylation and abstraction of $\mathrm{H}^{+}$ions resulted in formation of quinones (benzoquinone and hydroquinone). Continuous hydroxylation could result in form action of carboxylic acid, and acetic acid and carbon dioxide and water.

$$
\begin{aligned}
& 2 \mathrm{H}_{2} \mathrm{O} \rightarrow 2 \mathrm{OH}^{\cdot}+2 \mathrm{H}^{+}+2 \mathrm{e}^{-} \\
& \mathrm{H}_{2} \mathrm{O}+\mathrm{MO}_{\mathrm{x}} \rightarrow \mathrm{MO}_{\mathrm{x}}\left[\mathrm{OH}^{*}\right]+\mathrm{H}^{+}+\mathrm{e}^{-}
\end{aligned}
$$

Produced water contains high concentrations of salts which contribute as electrolyte during electrochemical treatment. $\mathrm{Cl}^{-}$ions are directly oxidized on the anode surface to produce molecular chlorine (Eq. 6) which reacts with $\mathrm{OH}^{*}$ ions to generate $\mathrm{ClO}^{-}$ion (Eq. 7) and also react with water molecules to form hypocholorous acid (Eq. 9). Because of interaction of $\mathrm{Cl}^{-}$ions some chlorinated phenolic compounds listed in Table 6 were also detected.

$$
\begin{aligned}
& 2 \mathrm{Cl}^{-} \rightarrow \mathrm{Cl}_{2}+2 \mathrm{e}^{-} \\
& \mathrm{Cl}_{2}+2 \mathrm{OH}^{\cdot} \rightarrow \mathrm{Cl}^{-}+\mathrm{ClO}^{-}+\mathrm{H}_{2} \mathrm{O} \\
& \mathrm{Cl}_{2}+\mathrm{H}_{2} \mathrm{O} \rightarrow \mathrm{HOCl}+\mathrm{H}^{+}+\mathrm{Cl}^{-} \\
& \mathrm{HOCl} \rightarrow \mathrm{H}^{+}+\mathrm{OCl}^{-}
\end{aligned}
$$

\section{Conclusion}

In this study, an effective electrochemical oxidation process is put forward for degradation of PAHs to reasonable extent using Ti/ 
Table 6. Analytical data of GC-MS chromatogram for intermedaites formed durring electrochemical oxidation.

\begin{tabular}{lccc}
\hline Identified intermediate compounds & Retention time & Peak area (\%) & Qualitative (\%) \\
\hline Dimethoxy-9-(2-penylethenyl)-9H-fluoren-9ol & 8.88 & 0.98 & 38 \\
Methyl 2,3-dihydro-1,4-benzodioxin-6-ylacetate & 11.06 & 1.39 & 40 \\
2,6-Dichlorophenol & 11.69 & 0.41 & 10 \\
Benzoic acid, 2,3-bis[(trimethylsi lyl)oxy]-, trimethylsilyl ester & 13.02 & 2.08 & 23 \\
Carbamic acid, N-(2,3-dimethylphen yl)-, oxiranylmethyl ester & 14.71 & 1.29 & 27 \\
Benzene-1-3-dicarboxylic acid-5-hydroxymehyl-diethyl ester & 15.35 & 0.45 & 9 \\
Carboxylic acid & 16.22 & 0.92 & 10 \\
1,2-Dihydro-2-methylpapaverine & 17.59 & 1.10 & 25 \\
Benzeneacetic acid & 18.83 & 0.52 & 32 \\
Benzene, 1,2-dichloro-3-nitro- & 19.09 & 0.40 & 9 \\
7-Chloro-4-methoxy-3-methylquinoline & 23.37 & 1.93 & 38 \\
\hline
\end{tabular}

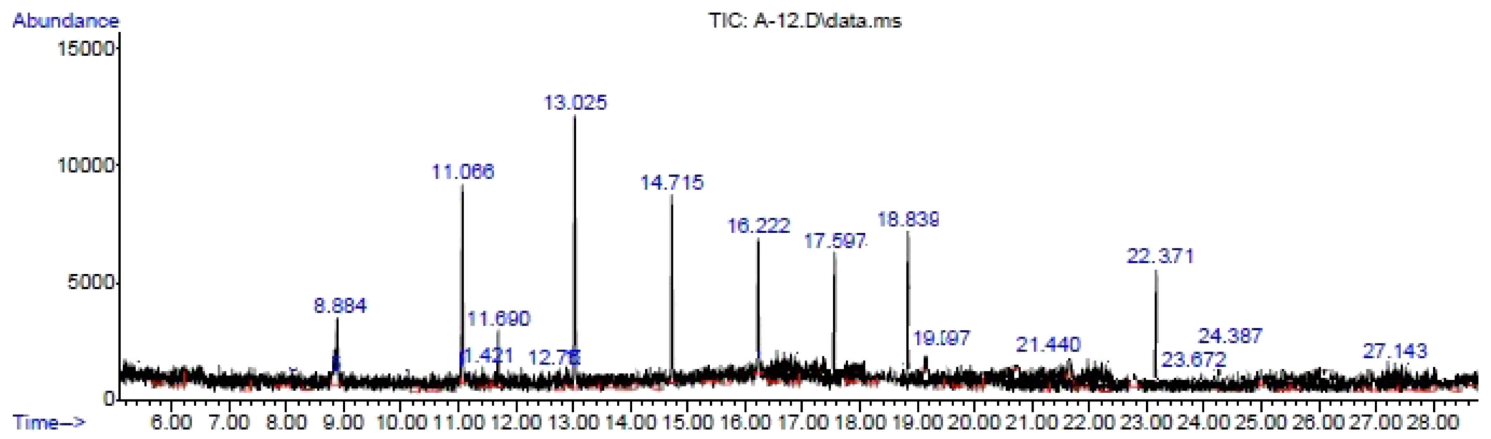

Figure 5. (Color online) GC-MS chromatogram of intermediates formed durring electrochemical oxidation using $\mathrm{Ti} / \mathrm{SnO}_{2}-\mathrm{Sb}_{2} \mathrm{O}_{5}-\mathrm{IrO}_{2}$.

$\mathrm{Sb}_{2} \mathrm{O}_{5}-\mathrm{SnO}_{2}-\mathrm{IrO}_{2}$ anode. $\mathrm{Sn}$ and $\mathrm{Sb}$, relatively cost effective materials for coating of anode, can be tested for industrial scale. $\mathrm{Ti} / \mathrm{Sb}_{2} \mathrm{O}_{5}-\mathrm{SnO}_{2}-\mathrm{IrO}_{2}$ anode worked on low current densities and short contact time which can be helpful in reducing energy consumption cost. $\mathrm{Ti} / \mathrm{Sb}_{2} \mathrm{O}_{5}-\mathrm{SnO}_{2}-\mathrm{IrO}_{2}$ anode also eliminates refractory byproducts and other pollutants. It can be used as an effective pre-treatment process with other conventional biological and physical and chemical treatments.

\section{References}

1. R. R. Reynolds, Produced Water and Associated Issues, a manual for independent operator, Petroleum Technology Transfer Council (2003).

2. J. A. Veil, M. G. Puder, D. Elcock, and R. J. Redweik, Jr., A White Paper Describing Produced Water from Production of Crude Oil, Natural Gas, and Coal Bed Methane, US DOE January (2004).

3. D. W. Woodall, R. P. Gambrell, and N. N. Rabalais, Mar. Pollut. Bull., 42, 1118 (2001).

4. E. N. Pakpahan, M. H. Isa, S. R. M. Kutty, S. Chantara, and W. Wiriya, Environ. Technol., 34, 407 (2013).

5. S. Meier, E. T. Andersen, L. Hasselberg, O. S. Kjesbu, J. Klugsøyr, and A. Svardal, Hormonal effects of C4-C7 Alkyphenols on cod (Gadusmorphua). Report to the Norwegian Oil Industry Association, Norwegian Institute of Marine Science, 68 (2002). Available on: http://www.imr.no/.

6. D. P. Anderson, Biological indicators of stress in fish, American Fishery Society Symposium 8, Maryland, p. 1 (1990).

7. E. J. Klekowski, J. E. Corredor, J. M. Morrel, and C. A. Del Castillo, Mar. Pollut. Bull., 28, 166 (1994).

8. A. G. Vlyssides, P. K. Karlis, N. Rori, and A. A. Zorpas, J. Hazard. Mater, 95 , 215 (2002).

9. Y. J. Feng and X. Y. Li, Water Res., 37, 2399 (2003).
10. A. Yaqub and H. Ajab, Rev. Chem. Eng., 29, 123 (2013).

11. A. Yaqub, H. Ajab, M. H. Isa, H. Jusoh, M. Junaid, and R. Farooq, J. New Mat. Electrochem. Systems, 15(4), 289 (2012).

12. A. Remes, M. Ihos, and F. Manea, Chem. Bull. "POLITEHNICA" Univ. (Timisoara), 55(69)2, 152 (2010).

13. G. H. Chen, X. M. Chen, and P. L. Yue, J. Phys. Chem. B, 106, 4364 (2002).

14. S. Kim, S. K. Choi, B. Y. Yoon, S. K. Lim, and H. Park, Appl. Catal., B, 97, 135 (2010).

15. H. B. Beer, "Electrode and coating therefor." U.S. Patent 3,632,498, issued January 4, 1972.

16. X. Chen, G. Chen, and P. L. Yue, J. Phys. Chem. B, 105, 4623 (2001).

17. A. Yaqub, M. H. Isa, S. R. M. Kutty, and H. Ajab, J. New Mater. Electrochem. Syst., 17, 39 (2014).

18. R. Chaiyont, C. Badoe, C. Ponce de León, J. L. Nava, F. J. Recio, I. Sires, and F. C. Walsh, Chem. Eng. Technol., 36, 123 (2013).

19. N. Matyasovszky, M. Tian, and A. Chen, J. Phys. Chem. A, 113, 9348 (2009).

20. M. Tian, L. Bakovic, and A. Chen, Electrochim. Acta, 52, 6517 (2007).

21. A. A. L. Zinatizadeh, A. R. Mohamed, A. Z. Abdullah, M. D. Mashitah, and M. H. Isa, Biochem. Eng. J., 35, 226 (2007).

22. L. Mohajeri, H. A. Aziz, M. H. Isa, and M. A. Zahed, Bioresour. Technol., 101, 893 (2010).

23. S. Mohajeri, H. A. Aziz, M. H. Isa, M. A. Zahed, M. J. K. Bashir, and M. N. Adlan, Water Sci. Technol., 61, 1257 (2010).

24. M. A. Zahed, H. A. Aziz, M. H. Isa, L. Mohajeri, and S. Mohajeri, Bioresour. Technol., 101, 9455 (2010).

25. M. A. Zahed, H. A. Aziz, L. Mohajeri, S. Mohajeri, S. R. M. Kutty, and M. H. Isa, J. Hazard. Mater., 184, 350 (2010).

26. A. D. Eaton and M. A. H. Franson, Standard methods for the examination of water \& wastewater. $21^{\text {st }}$ edition, American Public Health Association (2005).

27. A. Yaqub, M. H. Isa, S. R. M. Kutty, and H. Ajab, Appl. Mech. Mater, 567, 80 (2014).

28. A. Yaqub, M. H. Isa, and H. Ajab, J. Environ. Eng., (ASCE) (2014) Accepted.

29. X. Y. Li, Y. H. Cui, Y. J. Feng, Z. M. Xie, and J. D. Gu, Water Res., 39, 1972 (2005). 